https://helda.helsinki.fi

\title{
Isomalt and its diastereomer mixtures as stabilizing excipients with freeze-dried lactate dehydrogenase
}

\section{Tuderman, Anna-Kaisa}

2018-03-01

Tuderman , A-K , Strachan , C J \& Juppo , A M 2018 , ' Isomalt and its diastereomer mixtures as stabilizing excipients with freeze-dried lactate dehydrogenase ' , International Journal of Pharmaceutics , vol. 538 , no. 1-2 , pp. 287-295 . https://doi.org/10.1016/j.ijpharm.2018.01.015

http://hdl.handle.net/10138/309906

https://doi.org/10.1016/j.ijpharm.2018.01.015

cc_by_nc_nd

acceptedVersion

Downloaded from Helda, University of Helsinki institutional repository.

This is an electronic reprint of the original article.

This reprint may differ from the original in pagination and typographic detail.

Please cite the original version. 

EXCIPIENTS WITH FREEZE-DRIED LACTATE DEHYDROGENASE

9 a Formulation and Industrial Pharmacy, Division of Pharmaceutical Chemistry and Technology,

10 Faculty of Pharmacy, University of Helsinki, Helsinki, Finland

$12 *$ Corresponding author: Anna-Kaisa Tuderman, Viikinkaari 5E, 00014 Helsinki, Finland, tel.

$13+35840078$ 1239, fax +358 9191 59144, e-mail: anna-kaisa.koskinen@,helsinki.fi

14 E-mail addresses: clare.strachan@helsinki.fi, anne.juppo@helsinki.fi 
20 The purpose of this research was to study isomalt as a protein-stabilizing excipient with lactate

21 dehydrogenase (LDH) during freeze-drying and subsequent storage and compare it to sucrose, a standard freeze-drying excipient. Four different diastereomer mixtures of isomalt were studied. The

23 stability of the protein was studied with a spectrophotometric enzyme activity test and circular

24 dichroism after freeze-drying and after 21 days of storage at 16\% RH. Physical stability was analyzed with differential scanning calorimetry and Karl Fischer titration. Statistical analysis was utilized in result analysis. LDH activity was almost completely retained after freeze-drying with sucrose; whereas samples stabilized with isomalt diastereomer mixtures had a considerably lower protein activity. During storage the sucrose-containing samples lost most of their enzymatic

29 activity, while the isomalt mixtures retained the protein activity better. In all cases changes to 30 protein secondary structure were observed. Isomalt diastereomer mixtures have some potential as 31 protein-stabilizing excipients during freeze-drying and subsequent storage. Isomalt stabilized LDH moderately during freeze-drying; however it performed better during storage. Future studies with

33 other proteins are required to evaluate more generally whether isomalt would be a suitable excipient 34 for pharmaceutical freeze-dried protein formulations. 


\section{INTRODUCTION}

42 The number of proteins as active pharmaceutical ingredients in drug preparations has increased

43 during the last decade and it will continue to grow in the future. Biological products accounted for $23 \%$ of worldwide prescription and OTC sales in 2014 , with the corresponding number only $14 \%$ in 2006. The proportion is forecast to grow further, reaching $27 \%$ of all medicine sales worldwide in 2020 (EvaluatePharma 2015). Most of these biological products are monoclonal antibodies and recombinant products.

Because proteins are complicated and fragile molecules when it comes to their production, storage, and administration, developing protein pharmaceuticals is a challenge (Cromwell, et al. 2006). Many proteins are prone to chemical and/or physical degradation, which makes their

51 pharmaceutical formulation development difficult (Wang, et al. 2007). If stability of the protein in an aqueous liquid formulation is a problem, often the best choice is a freeze-dried formulation. The stability of proteins in freeze-dried (lyophilized) formulations is better than in aqueous solutions because the degradation reactions can be generally slowed down to such an extent that the protein drug will stay stable for months or years (Chang and Pikal 2009). The structure of many proteins may change during freeze-drying, at least partially, if they are not stabilized with excipients such as disaccharides or sugar alcohols i.e. polyols (Ohtake, et al. 2011), which are able to form an amorphous phase during freeze-drying. This protects proteins from freezing- and drying-induced degradation reactions. In addition, disaccharides and polyols may stabilize proteins after freezedrying in the dry state during storage. The excipients that are most commonly used for this purpose in protein formulations are sucrose and trehalose (Mensink, et al. 2017; Schwegman, et al. 2005). protein formulations is highly important because currently there are only a limited number of 
excipients that can be used for this purpose. The excipients currently used are not always able to stabilize all proteins sufficiently. Also, all stabilizing excipients have their own downsides since even trehalose, which is considered as the golden standard in protein stabilization and a good amorphous stabilizer, has been observed to crystallize during storage under frozen conditions (Singh, et al. 2011; Sundaramurthi and Suryanarayanan 2010). Because the number of protein drugs is going to increase in the future, broadening the range of excipients used for their formulation development is important.

Isomalt is a well-tolerated, non-toxic polyol, which is traditionally used as a sweetening agent in the food industry and as a tabletting excipient for pharmaceutical purposes (Ndindayino, et al. 2002; Sáska, et al. 2010; Sentko and Willibald-Ettle 2012). Isomalt is included in the British (BP), the European (PhEur) and the United States (USP-NF) pharmacopoeias as well as in Japanese Pharmaceutical Excipients (JPE) (British Pharmacopoeia Commission 2015; European Pharmacopoeia Online 9th Edition 2017; United States Pharmacopeial Convention 2014). Isomalt is a mixture of two stereoisomers, 6-O- $\alpha$-D-glucopyranosyl-D-sorbitol (1,6-GPS) and 1-O- $\alpha$-Dglucopyranosyl-D-mannitoldihydrate (1,1-GPM) (Sentko and Willibald-Ettle 2012). The structures of the diastereomers are presented in Figure 1. The glass transition temperatures of these stereoisomers are $66^{\circ} \mathrm{C}$ for $1,1-\mathrm{GPM}$ and $55^{\circ} \mathrm{C}$ for 1,6-GPS (Cammenga and Zielasko 1996). Isomalt does not belong to the group of reducing sugars that may cause an alteration in the degree of glycation of proteins in freeze-dried formulations during storage (Leblanc, et al. 2016). 
a)

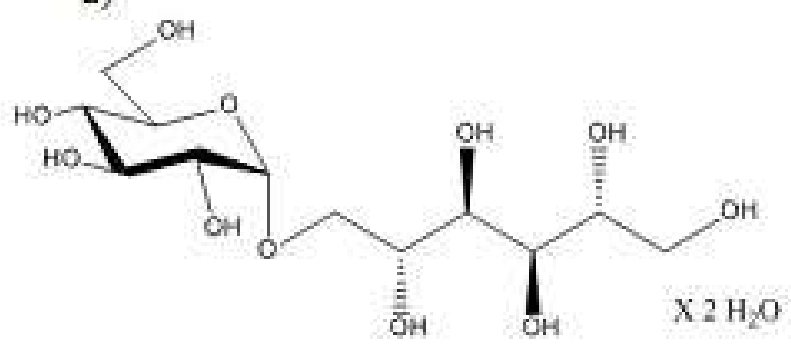

c)

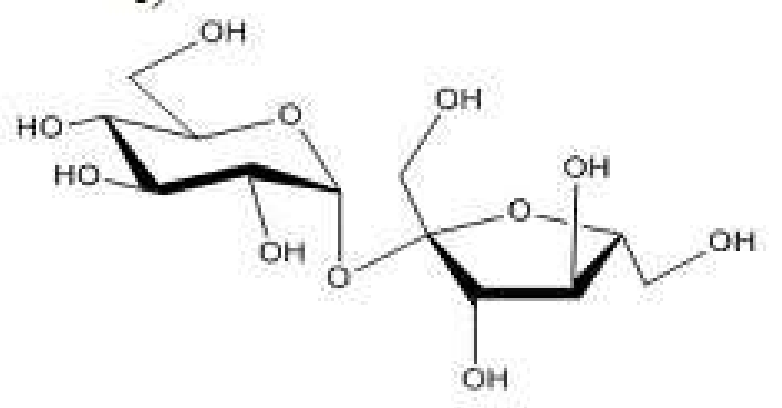

b)

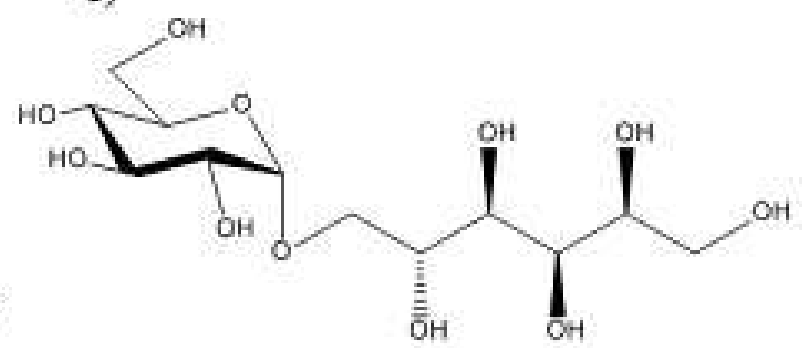

84

Fig. 1. The structures of a) GPM and b) GPS (the two diastereoisomers of isomalt, together comprising the polyol excipient) and c) sucrose

Acute toxicity of isomalt has been studied in rats and the $\mathrm{LD}_{50}$ dose was over $2500 \mathrm{mg} / \mathrm{kg}$ b.w. with the intravenous and intraperitoneal administration routes (Musch, et al. 1973). The chronic toxicity of orally administered isomalt as a part of diet has been studied in animals and it was found to be a safe substance. It did not affect the mortality rate of the animals, and there was no evidence of carcinogenicity, or adverse effects on fertility, reproductive performance or development (World Health Organization 1987). Furthermore, no maternal toxicity occurred and effects on embryonic, fetal development or reproductive performance were not observed (Smits-Van Prooije, et al. 1990; Waalkens-Berendsen, et al. 1990a; Waalkens-Berendsen, et al. 1990b; World Health Organization 1987). Isomalt has also been administered orally to humans. No significant changes in serum levels of glucose, insulin, lactic acid, hemoglobin, cholesterol, triglycerides, or high-density lipids were observed (Thiebaud, et al. 1984; World Health Organization 1987). Hepatic and renal function tests were within normal limits and no neurological and cardiovascular changes were observed after oral administration (World Health Organization 1987). 
101 To the best of our knowledge, no studies involving the use of isomalt as a protein stabilizing

102 excipient in freeze-dried formulations have been published. The physical properties of isomalt and

103 the fact that it is not a reducing sugar make it an interesting excipient to be studied in this context.

104 Some polyols, such as mannitol and sorbitol, tend to crystallise during freeze-drying and/or storage

105 (Al-Hussein and Gieseler 2012; Costantino, et al. 1998; Kadoya, et al. 2010), which reduces their

106 ability to stabilize proteins. Previously, we have characterized the solid state changes of isomalt and

107 its diastereomer mixtures during freeze-drying and storage in the absence of proteins (Koskinen, et

108 al. 2016). It was found that crystalline isomalt could be transformed into the amorphous form with

109 freeze-drying, and that during storage at up to $16 \% \mathrm{RH}$ amorphous isomalt had good physical

110 stability. The mixtures containing both diastereomers of isomalt, GPM and GPS, remained

111 physically more stable than a mixture containing only the GPM diastereomer. The amorphous

112 nature and good physical stability, which are important qualities for protein-stabilizing sugar

113 excipients, further increase the interest of studying whether isomalt is able to stabilize proteins

114 during freeze-drying and storage.

115 The aim of this study was to investigate the ability of isomalt, in four different diastereomer ratios,

116 to stabilize proteins during freeze-drying and subsequent storage with the model protein lactate

117 dehydrogenase (LDH). The cryo- and lyostabilizing effects of isomalt mixtures are evaluated by

118 protein activity measurements and secondary structure analysis. LDH is a widely used model

119 protein in freeze-drying related protein studies, and its activity can be quantified with a simple

120 spectrophotometric in vitro-test (Chatterjee, et al. 2005; Cochran and Nail 2009). Sucrose, a

121 traditionally used cryo- and lyoprotecting excipient in freeze-dried protein formulations, was used

122 as a reference in this study. The chemical structure of sucrose is presented in Figure 1. In addition to

123 the fact that sucrose is a relevant reference material because of its wide use in lyophilized protein

124 pharmaceuticals, it also shares some similar physicochemical properties with isomalt, such as

125 molecular mass, glass transition temperature, solubility in water at higher temperatures (over $50^{\circ} \mathrm{C}$ ), 
126 heat of fusion, heat of solution, and viscosity and water activity of aqueous solutions (Sentko and

127 Willibald-Ettle 2012).

128

\section{MATERIALS AND METHODS}

130

\subsection{Materials}

L-Lactic dehydrogenase from rabbit muscle in ammonium sulfate suspension (product number L2500), sucrose (product number 16104), and tris(hydroxymethyl)aminomethane (TRIS) (product number T6066) were acquired from Sigma-Aldrich Co. (St. Louis, Missouri, USA). One molar HCl (product number 30024.290) was obtained from VWR (Radnor, Pennsylvania, USA). Four different grades of isomalt (galenIQ ${ }^{\mathrm{TM}} 721$, galenIQ $^{\mathrm{TM}}$ 720, Isomalt GM and pure GPM-stereoisomer) were kindly donated by Beneo-Palatinit GmbH (Germany). By using the four supplied isomalt grades, the GPM-content of the freeze-dried samples was varied from 23.5 to $99 \%$ with the GPS-content varying from 0.0 to $75.7 \%$. Thus approximate GPM:GPS isomer ratios of 1:3 (galenIQ ${ }^{\mathrm{TM}} 721$ ), 1:1

141 (galenIQ ${ }^{\mathrm{TM}}$ 720), 2:1(Isomalt GM), and 1:0 (pure GPM-stereoisomer) could be studied. Highly purified water (Milli-Q, Millipore Inc., USA) was used in all of the studies.

143 The chemical formula of sucrose is $\mathrm{C}_{12} \mathrm{H}_{22} \mathrm{O}_{11}$ and those for isomalt are $\mathrm{C}_{12} \mathrm{H}_{24} \mathrm{O}_{11}$ and

$144 \mathrm{C}_{12} \mathrm{H}_{24} \mathrm{O}_{11} \cdot 2 \mathrm{H}_{2} \mathrm{O}$ for the anhydrous and dihydrate forms, respectively. The molecular structures of 145 sucrose and isomalt diastereomers share a common group, a glucose monomer and they have a 146 similar molecular mass (Figure 1). Besides a glucose ring, sucrose has a fructose ring in its 147 structure, whereas GPM and GPS isomers contain mannitol and sorbitol monomers instead of 148 fructose, respectively. 


\subsection{Preparation of the LDH solutions, freeze-drying and stability studies}

The acquired LDH suspension was initially dialyzed in $0.5 \mathrm{M}$ TRIS-HCl buffer solution ( $\mathrm{pH} 7.4$ ) to remove the ammonium sulfate prior to its use. This involved diluting $8 \mathrm{ml}$ of the LDH ammonium sulfate suspension with $8 \mathrm{ml}$ of TRIS-HCl buffer and transferring the suspension to a Spectra/Por ${ }^{\circledR}$ Biotech regenerated cellulose dialysis membrane, with molecular weight cut off $25000 \mathrm{Da}$ (Spectrum Laboratories Inc, Rancho Dominguez, California, USA). The membrane had previously been pretreated by soaking in purified water for 25 minutes. The resulting protein solution was dialyzed for $24 \mathrm{~h}$ in TRIS-HCl buffer and the buffer was replaced three times during the dialysis.

The dialyzed protein solution was diluted with $0.5 \mathrm{M}$ TRIS-HCl buffer to produce a solution with an $\mathrm{LDH}$ concentration of $0.5 \mathrm{mg} / \mathrm{ml}$. The concentration of the dialyzed protein stock solution was determined spectrophotometrically with UV-1600PC Spectrophotometer (VWR, Radnor, Pennsylvania, USA) at $280 \mathrm{~nm}$. The different isomalt grades or sucrose were added to the protein solution to produce a $100 \mathrm{mg} / \mathrm{ml}$ concentration of excipients, thus corresponding a 1:200 protein/excipient ratio. Protein solution with no added sugar excipient was also produced. Each of the produced solutions $(1 \mathrm{ml})$ was pipetted into $20 \mathrm{ml}$ freeze-drying vials and freeze-dried using a Lyostar II freeze-dryer (SP Industries Inc., Warminster, USA). The vials were first equilibrated at $16720^{\circ} \mathrm{C}$ for 10 minutes and then at $0^{\circ} \mathrm{C}$ for 30 minutes. The samples were then frozen at $-40^{\circ} \mathrm{C}$ for 2 168 hours. The freezing ramp rate was $1^{\circ} \mathrm{C} / \mathrm{min}$. Primary drying was performed with a shelf temperature of $-30^{\circ} \mathrm{C}$ and pressure of 150 mTorr for 18 hours. Secondary drying was carried out by heating the chamber $0.1^{\circ} \mathrm{C} / \mathrm{min}$ to $35^{\circ} \mathrm{C}$, while retaining the pressure at $150 \mathrm{mTorr}$. Maintaining the pressure in

171 the same level during primary and secondary drying was found to work with isomalt samples in a 172 previous study (Koskinen, et al. 2016). After the freeze-drying cycle was complete, the chamber 
temperature was lowered from $35^{\circ} \mathrm{C}$ to $25^{\circ} \mathrm{C}$ and the chamber was filled with $\mathrm{N}_{2}$ gas to bring the pressure inside the chamber back to atmospheric pressure. The vials were then stoppered in the $\mathrm{N}_{2}$ atmosphere inside the chamber by compression before opening the chamber door.

The vials intended for storage stability studies were transferred into a desiccator containing a saturated salt solution of lithium chloride, thus producing a relative humidity of approximately $16 \%$. In our previous study even this low relative humidity condition was observed to cause stress to the physical stability of freeze-dried isomalt samples stored in the desiccator without stoppers (Koskinen, et al. 2016), and was thus chosen to this current study. The vials were opened inside the desiccator and were stored without stoppers at ambient temperature of approximately $22^{\circ} \mathrm{C}$. The humidity percentage inside the desiccator was monitored with a Tinytag data logger (Gemini Data Loggers, Chicester, United Kingdom). The samples were stored in the desiccator for 21 days.

\subsection{Protein activity measurements}

\section{LDH activity was measured using a lactate dehydrogenase activity assay kit (product number} MAK066) acquired from Sigma-Aldrich Co. (St. Louis, Missouri, USA). The freeze-dried samples were first rehydrated with $1 \mathrm{ml}$ of purified water and then diluted to an LDH concentration of 0,005 mg/ml and pipetted into a Nunc MicroWell 96-well plate (Thermo Fisher Scientific, Massachusetts, USA), after which the reagents of the activity assay kit were added to the wells. The measurements were performed at $37^{\circ} \mathrm{C}$ with a Varioskan Flash spectrophotometer (Thermo Fisher Scientific, Massachusetts, USA) and the readings were collected with SkanIt software (Thermo Fisher Scientific, Massachusetts, USA). Each sample was studied in triplicate from different vials ( $\mathrm{n}=3$ ) and two parallel wells were made from each vial. Thus the protein activity results are presented as mean values of six measurements. The mean well-to-well variation between duplicate samples was 
14,21\% (minimum 0,09\%, maximum 81,41\%). LDH activity was measured before freeze-drying, after freeze-drying and after 3 weeks of storage. LDH activity of the lyophilized samples was compared to the activity of unprocessed LDH by calculating the relative activity remaining after processing.

\subsection{Differential scanning calorimetry}

Differential scanning calorimetry (DSC) was used to monitor the thermal behavior and solid state properties of the lyophilized samples and raw materials. The freeze-dried LDH samples were studied after freeze-drying and after 3 weeks of storage. Approximately 3-7 mg of the sample was transferred in an aluminum DSC pan and closed with a pierced lid to allow free water evaporation during measurements. Each sample was made in triplicate and the samples were taken from different vials $(\mathrm{n}=3)$. The DSC experiments were carried out by first equilibrating the samples at $25^{\circ} \mathrm{C}$ for 3 minutes and then heating them at $10^{\circ} \mathrm{C} / \mathrm{min}$ to $180^{\circ} \mathrm{C}$ for isomalt samples, or to $160^{\circ} \mathrm{C}$ for sucrose samples, in order to avoid sample spillage from the pans. The runs were carried out under $50 \mathrm{ml} / \mathrm{min} \mathrm{N}_{2}$ purge. The results were analyzed with $\mathrm{STAR}^{\mathrm{e}}$ Thermal Analysis Software (MettlerToledo International Inc., Greifensee, Switzerland).

\subsection{Circular dichroism}

17 Circular dichroism (CD) was used to study if the secondary structure of LDH changes during freeze-drying or storage. The freeze-dried samples were rehydrated with $1 \mathrm{ml}$ of purified water and diluted to one fifth of the original concentration. The CD spectra of the samples were measured 
with a Jasco J-720 spectrometer (Jasco Inc., Easton, Maryland, USA). Samples were scanned in the

221 far UV range from 200 to $250 \mathrm{~nm}$ at a speed of $50 \mathrm{~nm} / \mathrm{min}$, an increment of $1 \mathrm{~nm}$ and a response 222 time of $1 \mathrm{~s}$. A quartz cuvette with a path length of $1 \mathrm{~mm}$ was used and each final spectrum was an averaged from three consecutive scans. The spectra were smoothed with a Savitzky-Golay function using a convolution width of 13 points. The measured average ellipticity was converted to mean

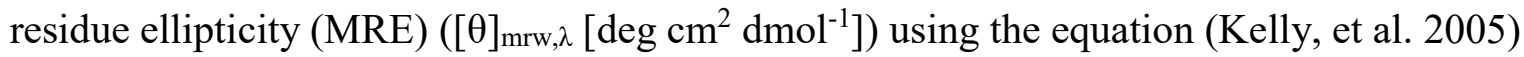

$$
[\theta]_{\mathrm{mrw}, \lambda}=\left(\mathrm{MRW} \cdot \theta_{\lambda}\right) /(10 \cdot \mathrm{d} \cdot \mathrm{c})
$$

where MRW was mean residue weight, using $111.2 \mathrm{~g} / \mathrm{mol}$ for the studied protein, $\theta_{\lambda}$ was the measured average ellipticity, $\mathrm{d}$ was pathlength $(\mathrm{cm})$, and c was concentration $(\mathrm{g} / \mathrm{ml})$. The CD spectrum of LDH was measured before freeze-drying, after freeze-drying, and after 3 weeks of storage. Also the spectrum of denatured LDH was measured after equilibrating it for 10 min with 1 M HCl. In addition to that, the excipient solutions without LDH were studied in order to verify that the excipients did not interfere with the CD spectrum of LDH in the studied UV region.

\subsection{Water content measurements}

The residual water content of the freeze-dried LDH samples was measured with Karl-Fischer titration (KF). The measurements were carried out after freeze-drying and during storage with a V30 Volumetric KF Titrator (Mettler-Toledo International Inc., Greifensee, Switzerland). The KF measurements were conducted from the same sample vials as the DSC experiments. Rubber stoppers were immediately placed on the vials when taking them out of the desiccator and all possible steps were taken to minimize ambient moisture uptake between DSC and KF analyses, specifically the vials were stoppered immediately after taking out powder samples from the vials and the analyses were conducted as rapidly as possible. The lyophilization vial was weighed, the 
244 residual sample amount was poured into the KF titration vessel and the vial was weighed yet again

245 to calculate the sample mass. The water content results are presented as an average of three sample 246 vials.

\subsection{Statistical analysis}

250 Results obtained from the LDH activity measurements were analyzed using independent samples 251 Kruskal-Wallis test. The analyses were performed on the results of different sample vials $(\mathrm{n}=3)$ of 252 each treatment (unprocessed, freeze-dried without sugars or freeze-dried with isomalt/sucrose). 253 Analyses were performed using IBM SPSS Statistics software version 23.0 (IBM Corp., Armonk, 254 NY, USA). For all analyses, p-values of $<0.05$ were considered to be statistically significant.

\section{RESULTS AND DISCUSSION}

\subsection{Secondary structure}

CD spectroscopy was performed on the unprocessed protein as well as on the freeze-dried protein

261 formulations with excipients before and after storage. The measured CD spectrum of unprocessed 262 LDH with its two ellipticity minima at around 209 and $222 \mathrm{~nm}$ agree well with previous CD studies 263 of LDH (Kouassi, et al. 2007; Mi, et al. 2002; Mi and Wood 2004). Based on the CD spectroscopy 264 measurements, the secondary structure of LDH freeze-dried with sugar excipients was altered to 265 some extent (Figure $2 \mathrm{a}, \mathrm{b}$ ). However, an absence of isomalt or sucrose precipitated more significant 
266 LDH secondary structure changes, displayed as a higher increase in MRE. A reference CD

267 spectrum of non-lyophilized LDH denatured with $\mathrm{HCl}$ shows a complete destruction of the 268 secondary structure of LDH. Overall, both isomalt and sucrose had a significant effect in preserving 269 the secondary structure of LDH during lyophilization. All LDH samples with different sugar 270 excipients had a very similar CD spectrum. As such, no clear differences could be resolved in the 271 secondary structure of LDH stabilized with either different isomalt grades or sucrose (Figure 2 a). 
a)

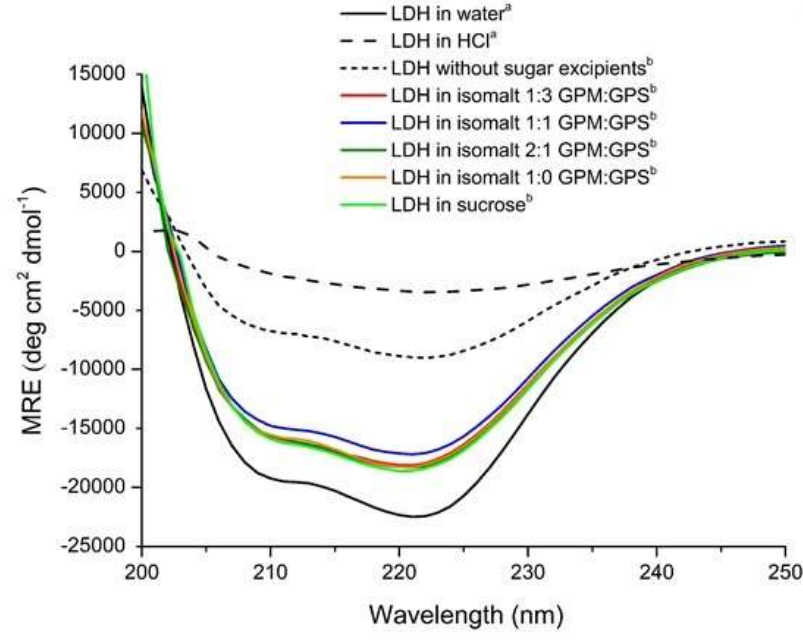

c)

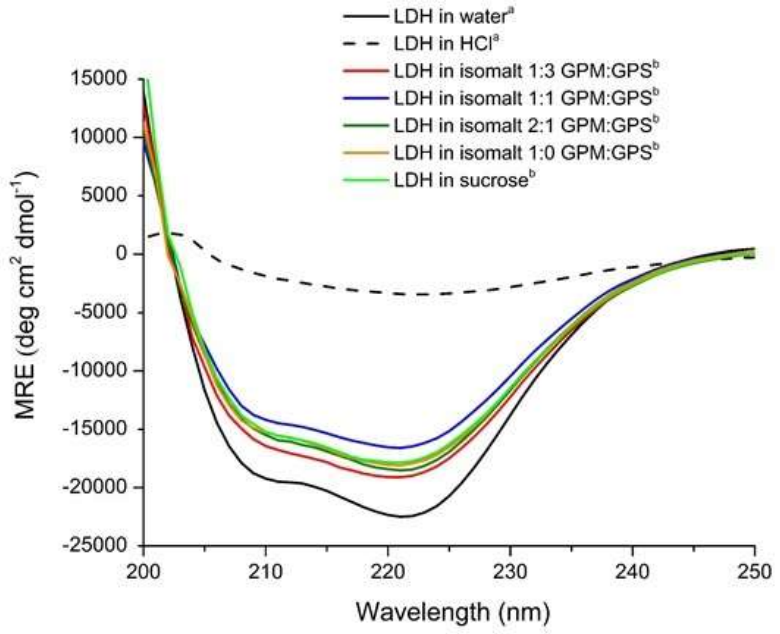

e)

The CD spectra of isomalt- and sucrose-containing samples after 3 weeks of storage were slightly
)

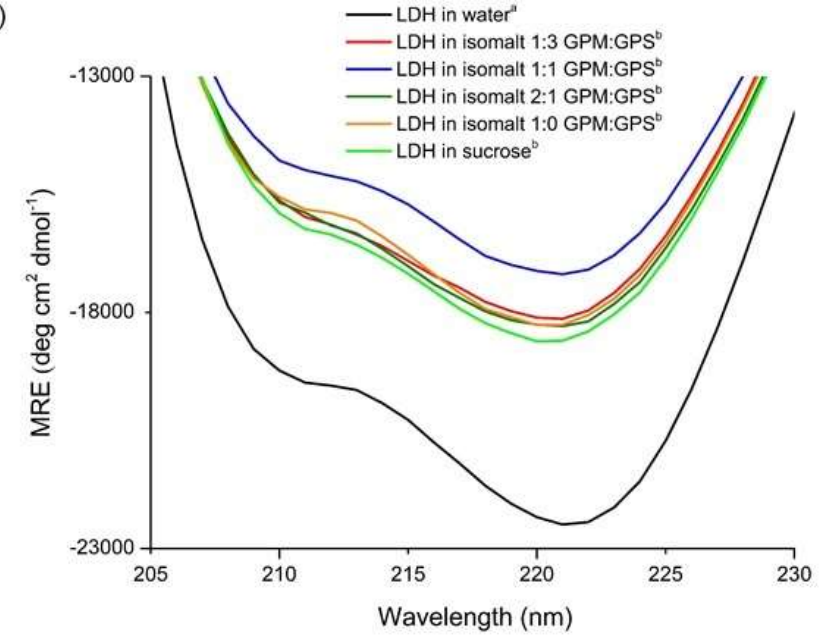

d)
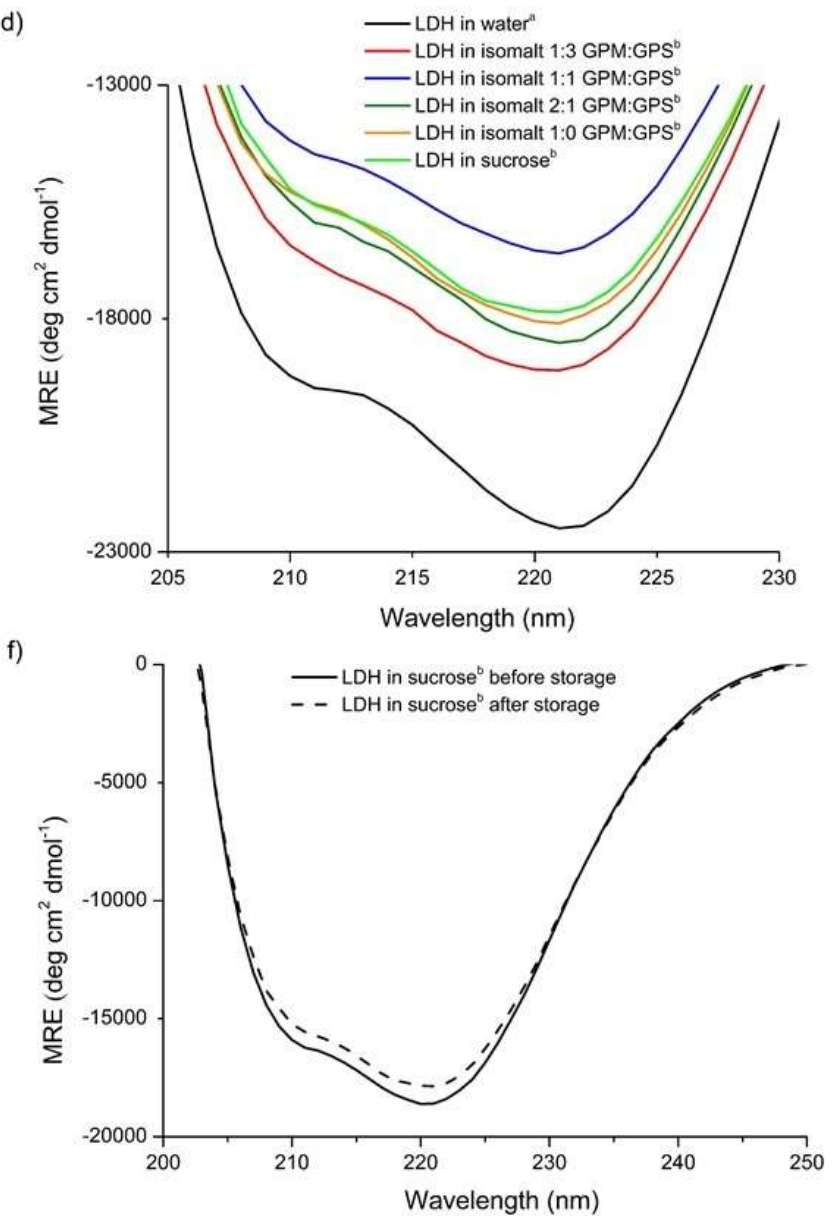

Fig. 2. The CD spectra of a) LDH samples after freeze-drying with zoom in (b), c) LDH samples after 3 weeks of storage at 16\% RH with zoom in (d), LDH before and after storage with e) $1: 1$ GPM:GPS and f) sucrose. Reference spectra of unprocessed LDH in water and denatured LDH in $\mathrm{HCl}$ are included. ${ }^{\mathrm{a}}$ non-lyophilized samples ${ }^{\mathrm{b}}$ lyophilized samples

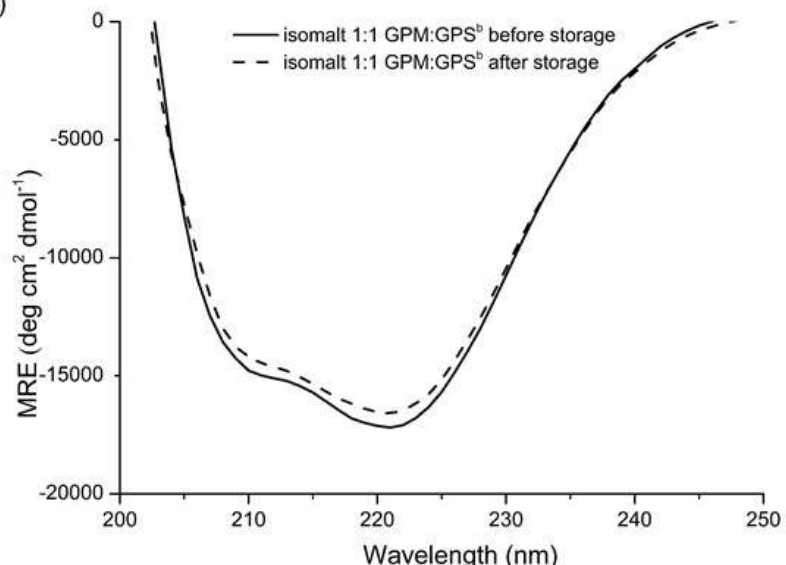


282 (Figure 2 c-f). The two ellipticity minima around 209 and 222 were not as distinct as in the spectra 283 of both untreated LDH and lyophilized samples with sugars before storage. As an example of the 284 samples having the most changes during storage, the CD spectra of LDH with 1:1 GPM:GPS and sucrose before and after storage are illustrated in Figures 2 e and f. The predominant secondary structure of LDH is $\alpha$-helix with $39.2 \%$ of the residues in this conformation, $22.4 \%$ in $\beta$-sheet conformation and $38.4 \%$ in other secondary structures (Kouassi, et al. 2007). Loss in ellipticity observed with LDH both after freeze-drying and after storage with and without the sugars resulted in decrease in the $\alpha$-helix content and increase in the content of $\beta$-sheet and other conformations (Kouassi, et al. 2007). When comparing the spectra of after-storage samples containing different isomalt grades or sucrose to one another and to the spectrum of unprocessed LDH, only small differences could be observed between the excipients. After storage, the isomalt grade containing a ratio of 1:3 GPM:GPS had the smallest increase in MRE compared to the spectrum of unprocessed LDH, and the spectrum of 1:1 GPM:GPS had the highest increase in MRE. The spectra of two other isomalt grades, 2:1 and 1:0 GPM:GPS, and sucrose were in between the former two in regards to their increase in MRE. Based on this, the isomalt grade with a 1:1 GPM:GPS ratio did not preserve 297 the secondary structure of LDH during storage as well as the other isomalt grades or sucrose.

298 Because the differences between isomalt and sucrose were overall quite small, it can be concluded that during freeze-drying and subsequent storage at $16 \% \mathrm{RH}$ isomalt and sucrose preserved the secondary structure of LDH equally well.

\subsection{Protein activity}

The measured LDH activity of samples lyophilized with sugars varied depending on the excipient. 
drying (Figure 3). The four different isomalt grades showed slight variation between the GPM:GPS

307 diastereomer mixtures, the 1:3 GPM:GPS samples having the highest LDH activity after

308 lyophilization. During storage, the LDH activity decreased in all samples with sucrose-containing 309 samples having the highest absolute loss in LDH activity.

310 The enzymatic activities of different samples were analyzed with Kruskal-Wallis test to observe

311 statistically relevant differences between the groups. A difference was observed between groups of 312 different treatments before the storage period $(\mathrm{p}<0.0004)$. Based on the results of LDH activity 313 results and statistical analysis, sucrose stabilized LDH best and samples stabilized with isomalt or 314 containing no sugar excipients showed lower protein activities compared unprocessed LDH and 315 sucrose-containing samples.

316 During storage LDH activity decreased in all samples. Sucrose-containing samples had the highest 317 absolute loss in LDH activity during storage, from 95.6 to $37.2 \%$ (relative to unprocessed LDH 318 activity). Between different isomalt grades the variation in LDH activity loss was relatively small, 319 though 2:1 GPM:GPS-containing samples retained their LDH activity the best, the loss being only $320 \quad 1.5 \%$ units, from $52.1 \%$ before storage to $50.6 \%$ after storage. Compared to the samples containing 321 no stabilizing excipients, all sugar-containing samples retained a higher level of LDH activity after 322 storage. When no sugars were included in the sample, LDH activity was lost almost completely 323 with only $10.9 \%$ remaining after storage (Figure 3 ). As in the case of statistical analysis of pre324 storage results, Kruskal-Wallis test observed a difference between the different groups after the 325 storage period $(\mathrm{p}=0.006)$. Unprocessed LDH was not included in the analysis, so only post-storage 326 activity results of freeze-dried samples were compared to each other. This suggests that some or all 327 sugar excipients stabilized LDH better compared to samples containing no isomalt/sucrose. 


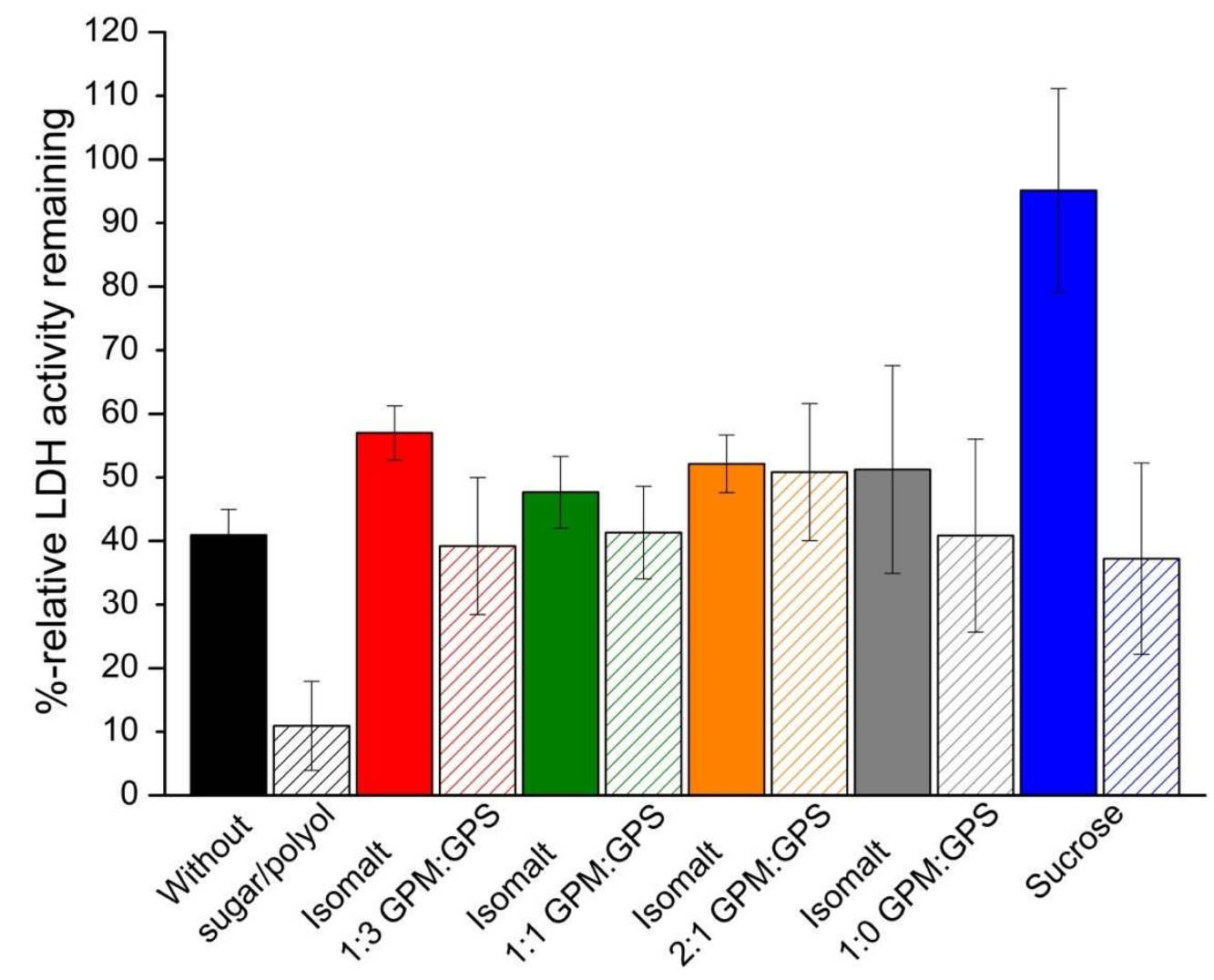

Fig. 3. Relative LDH activity after freeze-drying (solid bars) and after storage (dashed bars) with and without sugar excipients (mean $\pm \mathrm{sd}$ )

In previous studies, when LDH has been freeze-dried without any stabilizing excipients, LDH activity recoveries between 22.2 and $68.5 \%$ have been recorded, and the remaining LDH activity after lyophilization of $40.9 \%$ observed in this current study falls in the middle range of these previous observations (Anchordoquy, et al. 2001; Kadoya, et al. 2010; Luthra, et al. 2007). The concentration of LDH itself also has an effect on its recovery after lyophilization, for it has been observed that as the concentration increases, the remaining LDH activity also increases progressively (Anchordoquy and Carpenter 1996). In a previous study, the recovery of LDH increased approximately from 20 to $55 \%$ as the LDH concentration was varied between 25 and 500 $\mu \mathrm{g} / \mathrm{ml}$, respectively (Anchordoquy and Carpenter 1996). Primary drying does not appear to be a critical step in the freeze-drying process of $\mathrm{LDH}$, for no activity loss was observed even in the absence of any stabilizing excipients, thus secondary drying seems to be the critical phase in the 
344 lyophilization process with respect to retaining LDH activity (Jiang and Nail 1998; Luthra, et al. 345 2007).

346 The difference between sucrose and the four isomalt grades in their stabilizing effects during 347 lyophilization are better resolved from the $\mathrm{LDH}$ activity measurements than from the $\mathrm{CD}$ 348 spectroscopy measurements. The ability of sucrose to preserve a higher activity level of LDH 349 during freeze-drying was not observed in the CD spectra when comparing sucrose to isomalt, for 350 their spectra were very similar compared to each other. LDH freeze-dried without sugar excipients 351 had the lowest remaining activity after freeze-drying and this confirms the CD spectroscopy results, 352 which indicated greater alterations in the secondary structure of LDH lyophilized without sugars.

353 The observed loss in LDH activity during storage in samples containing sugars is confirmed by the 354 CD spectroscopy results as the spectra measured after storage lost some of their shape in the two 355 ellipticity minima compared to pre-storage spectra. The better ability of isomalt to stabilize LDH 356 during storage compared to sucrose observed from the results of protein activity measurements did 357 not show as clear differences in their CD spectra measured after storage. Based on the measured CD 358 spectra, the loss in activity during storage was partly due to alterations on the secondary structure of $359 \mathrm{LDH}$, but also other factors presumably had an effect on the loss of protein activity, especially in 360 the case of LDH stabilized with sucrose, which lost most of its activity during storage. Aggregation 361 is one of the most important reasons to cause physical instability to proteins and it may be one 362 possible reason of causing loss in activity during storage in this present investigation (Wang, et al. 363 2007).

364 Out of all the studied excipients, sucrose was the best cryo- and lyostabilizing excipient. All isomalt 365 grades stabilized LDH during freeze-drying producing higher LDH activity values compared to 366 LDH freeze-dried without any sugar excipients, 1:3 GPM:GPS stabilizing LDH best out of the 367 different isomalt grades. Especially during storage, the protein stabilizing effects of different 
368 isomalt grades were observed. The protein samples containing isomalt preserved LDH activity

369 better during storage compared to the samples without any sugar excipients. Sucrose has been used 370 as a cryo- and lyostabilizing excipient with LDH in previous studies, and as in this current study, 371 sucrose has been able to successfully retain a high LDH activity after freeze-drying and it is also 372 observed to stabilize LDH after freeze-thawing (Anchordoquy, et al. 2001; Kadoya, et al. 2010; 373 Luthra, et al. 2007). Sucrose in concentrations of $0.025 \mathrm{~mol} / 1,0.1 \mathrm{~mol} / 1$ and $0.5 \mathrm{~mol} / 1$ with an LDH 374 concentration of $0.25 \mathrm{mg} / \mathrm{ml}$, thus corresponding approximate protein/excipient ratios of 1:34, 1:137 and $1: 685$, retained $60.4 \%, 87.1 \%$ and $84.7 \% \mathrm{LDH}$ activity after freeze-drying, respectively (Anchordoquy, et al. 2001). In another study, $50 \mathrm{mg} / \mathrm{ml}$ sucrose resulted in almost complete LDH activity recovery after freeze-drying $(94.0 \%)$, but lower concentrations $(0.05,0.5$ and $5 \mathrm{mg} / \mathrm{ml})$ resulted in no stabilization or only partial activity recovery (Luthra, et al. 2007). Unfortunately, the ratio of protein to excipient cannot be calculated, as the LDH concentration of the samples was not specified. In the current study, all of the studied sugars stabilized the protein against destabilizing effects of moisture during storage better than when no sugars were included in the samples. Isomalt performed better than sucrose during storage, for the loss in LDH activity in samples containing different isomalt grades was only moderate compared to sucrose-containing samples. The protein 384 activity of samples stabilized with sucrose decreased considerably during storage as a result of the 385 effect of moisture. In a previous study, at high storage temperatures ( 40 or $\left.60^{\circ} \mathrm{C}\right)$ sucrose with a protein/excipient ratio of 1:1 000 was not able to stabilize LDH when the moisture content of the samples was high $(5.6 \% \mathrm{w} / \mathrm{w})$, but at a lower storage temperature of $20^{\circ} \mathrm{C}$ it performed well as a 388 stabilizing excipient, retaining LDH activity in the same level before and after 90 days of storage 389 (Kawai and Suzuki 2007). Compared to these previous results, the inferior ability of sucrose to 390 stabilize LDH during storage in this current study can result from the five times lower 391 protein/excipient ratio used in this study. A very high protein/excipient ratio of sucrose (1:2 000) 
has been found to stabilize $\mathrm{LDH}$ at a high storage temperature of $50^{\circ} \mathrm{C}$ during a 7-day storage period (Kadoya, et al. 2010).

The mechanisms by which disaccharides and polyols stabilize proteins during the stresses caused by 395 lyophilization have been widely studied, although the discovered mechanisms are not universally approved and are still under more in-depth investigation. Multiple different mechanisms have been found to affect protein stabilization. In liquid state and during the freezing stage of lyophilization, sugars and polyols stabilize proteins by the preferential exclusion mechanism, which means that the stabilizing excipients are preferentially excluded from the surface of the protein as the protein 400 molecules prefer to interact with water molecules (Timasheff 1998). This thermodynamically 401 stabilizes multimeric proteins, like LDH, against stress-induced dissociation, because LDH can undergo low-temperature-induced subunit dissociation that leads to irreversible structural changes 403 (Anchordoquy, et al. 2001; Jaenicke 1990). A high concentration of sucrose or isomalt used in this 404 current study increases the viscosity of the solutions, which can also stabilize LDH during the 405 freezing stage by restricting diffusion of the solute molecules and minimizing the rate of chemical 406 reactions (Hagen, et al. 1995). During freeze-drying, sucrose and isomalt are transformed from 407 crystalline excipients to amorphous (Carstensen and Van Scoik 1990; Koskinen, et al. 2016), which 408 enables them to stabilize LDH during the drying stage of lyophilization by forming a glassy matrix, 409 in which the protein is stabilized by reduction of conformational changes and by conformational 410 relaxation (Hagen, et al. 1995). The formation of a viscous glassy matrix is considered to be one of 411 the most important stabilization mechanisms of sugars and polyols in general (Hagen, et al. 1995; 412 Kadoya, et al. 2010). Despite this, according to one previous study, it appears that formation of a 413 glassy matrix is not important for protection of LDH during freezing (Anchordoquy, et al. 2001). 414 According to another previous study, preferential exclusion during freezing and vitrification during 415 drying combined with water substitution might explain how sucrose is able to stabilize LDH during 416 freeze-drying (Luthra, et al. 2007). Another important stabilization mechanism of sugars is 
417 hydrogen bonding (Allison, et al. 1999). Sucrose, along with other sugar excipients, is able to 418 hydrogen-bond to dried proteins, and because of this they are able to inhibit the loss of LDH 419 activity during dehydration by preventing protein unfolding (Anchordoquy, et al. 2001). Isomalt 420 and sucrose share one common group, a glucose monomer, in their structures (Figure 1). Besides a 421 glucose ring, sucrose has a fructose ring in its structure, whereas GPM and GPS isomers contain 422 mannitol and sorbitol monomers instead of fructose. The differences in hydrogen bond formation 423 between isomalt or sucrose and a protein therefore result from the latter part of the structures. Both 424 isomalt and sucrose contain $\mathrm{OH}$-groups that can hydrogen bond to proteins. Theoretically, sucrose 425 and isomalt could both stabilize LDH by hydrogen bond formation equally well, but since protein 426 stabilization mechanisms are still under speculation, hydrogen bond formation is only one of many 427 mechanism behind protein stabilization. According to Allison et al. (1999) hydrogen bonding 428 efficiency between proteins and sugars varies according to their structures, and differences between 429 sugars in their ability to stabilize proteins may be partially due to differences in the extent and 430 intimacy of hydrogen bond formation. Despite similarities in the molecular structures of sucrose 431 and isomalt, it cannot be excluded that differences in the extent and intimacy of hydrogen bond 432 formation to LDH could exist. This may be one explanation why sucrose stabilized LDH better than 433 isomalt during freeze-drying.

\subsection{Physical properties}

437 The freeze-dried samples did not have a perfect cake structure. In particular, the samples containing 438 sucrose and isomalt in 1:3 or 1:1 GPM:GPS ratios had collapsed, suggesting that the freeze-drying 439 cycle could have been further optimized. The protein activity after freeze-drying increased in the 440 order; without sugar/polyol < 1:1 GPM:GPS < 1:0 GPM:GPS < 2:1 GPM:GPS < 1:3 GPM:GPS < 
sucrose. Therefore despite their collapse during lyophilization, samples containing sucrose and 1:3

442 GPM:GPS had the highest protein activities. In previous studies with collapsed lyophilizates it was 443 observed that collapse during freeze-drying did not negatively affect stability, and even better 444 protein stability was observed in collapsed cakes compared to non-collapsed (Fonte, et al. 2014; 445 Schersch, et al. 2010). After storage, the LDH activity had decreased the most relative to pre446 storage activity in the order; without sugar/polyol $>$ sucrose $>1: 3$ GPM:GPS $>1: 0$ GPM:GPS $>1: 1$ 447 GPM:GPS > 2:1 GPM:GPS. Based on this, it may be possible that the observed collapse during 448 freeze-drying in samples containing sucrose, 1:3 GPM:GPS and 1:1 GPM:GPS may have had a 449 negative effect on their storage stability, although in a series of studies with several proteins, 450 including LDH, it was observed that lyophilizate collapse during freeze-drying did not negatively 451 affect protein stability even during long-term storage; however collapse during storage was 452 associated with decreased protein stability (Schersch, et al. 2010; Schersch, et al. 2013; Schersch, et al. 2012). No additional collapse was observed in this current study during storage.

The freeze-dried samples were studied with DSC before and after storage to study their solid state properties, including confirming whether they were amorphous or crystalline. All samples measured after freeze-drying and 3 weeks of storage exhibited a glass transition temperature $\left(\mathrm{T}_{\mathrm{g}}\right)$. This and the absence of a crystallization exotherm and a melting endotherm suggest that they were amorphous after freeze-drying and remained so during the 3 weeks of storage at $16 \% \mathrm{RH}$ (Table 1). The 460 approximately $10^{\circ} \mathrm{C}$ lower $\left(53.7^{\circ} \mathrm{C}\right)$ due to the moisture content rising from $1.9 \%$ before storage to $4613.0 \%$ after storage. A $\mathrm{T}_{\mathrm{g}}$ of $68.5^{\circ} \mathrm{C}$ has previously been measured for pure, dry sucrose (Urbani, et 462 al. 1997).

463 The $\mathrm{T}_{\mathrm{g}}$ of samples containing isomalt varied depending on the ratio of GMP and GPS. After freeze464 drying, the samples containing a 1:3 ratio of GPM and GPS had the lowest $\mathrm{T}_{\mathrm{g}}$ of $40.3^{\circ} \mathrm{C}$, and the $\mathrm{T}_{\mathrm{gS}}$ 465 of other isomalt grades were $49.3,51.5$ and $58.9^{\circ} \mathrm{C}$ for samples containing $1: 1,2: 1$ and 1:0 
GPM:GPS ratios, respectively. As might be expected, and also observed in a previous study with

467 amorphous isomalt (Koskinen, et al. 2016), the samples' residual moisture contents had an effect on 468 their $\mathrm{T}_{\mathrm{g}} \mathrm{s}$ : as the $\mathrm{T}_{\mathrm{g}}$ of isomalt samples grew higher, their moisture contents decreased. After freeze469 drying, residual moisture contents of 3.6, 3.1, 2.6 and 2.2\% were recorded for the 1:3, 1:1, 2:1 and 470 1:0 GPM:GPS ratios, respectively. The $\mathrm{T}_{\mathrm{gS}}$ of pure isomalt grades have been studied previously, 471 with values of $42.4,51.4,54.4$ and $62.4^{\circ} \mathrm{C}$ being reported for the 1:3, 1:1, 2:1 and 1:0 ratios of 472 GPM:GPS, respectively (Koskinen, et al. 2016). During storage at $16 \% \mathrm{RH}$, the water contents of the samples increased by $0.4-1.1$ percentage units 474 (Table 1). Consequently, the $\mathrm{T}_{\mathrm{g}}$ after storage were lower than pre-storage values, at $36.7,40.5$, 475 45.1 and $48.7^{\circ} \mathrm{C}$ for the 1:3, 1:1, 2:1 and 1:0 GPM:GPS ratios, respectively. In a previous study, freeze-dried pure isomalt samples containing the GPM:GPS ratios of 1:3, 1:1, 2:1 and 1:0 and stored at $16 \% \mathrm{RH}$ for 23 days exhibited $\mathrm{T}_{\mathrm{g}}$ values of $39.3,41.5,43.3$ and $45.3^{\circ} \mathrm{C}$, respectively 478 (Koskinen, et al. 2016).

479 Compared to the pure isomalt samples in similar storage conditions, which exhibited crystallization 480 peaks in the thermograms of 1:3 and 1:0 GPM:GPS samples (Koskinen, et al. 2016), no other 481 thermal events, except dehydration, were detected after storage in the measured thermograms of this 482 current study. The isomalt $\mathrm{T}_{\mathrm{g}}$ and moisture content changes during storage did not predict the 483 changes observed in LDH stability during storage. Having said this, the 2:1 GPM:GPS mixture, 484 which stabilized the protein best, exhibited a modest decrease in $\mathrm{T}_{\mathrm{g}}$ and rise in residual water 485 content when compared to sucrose samples, the $\mathrm{T}_{\mathrm{g}}$ of which decreased markedly with a concurrent 486 large increase in water content, suggesting that the protein stability could partly be due to changes 487 in physical stability. 
494 Table 1. Glass transitions and residual water contents (mean $\pm \mathrm{sd}, \mathrm{n}=3$ )

\begin{tabular}{|c|c|c|}
\hline & $\mathbf{T}_{\mathrm{g}}$ (midpoint) & $\begin{array}{c}\text { Residual water } \\
\text { content }\end{array}$ \\
\hline & {$\left[{ }^{\circ} \mathrm{C}\right]$} & $(\mathrm{w} / \mathrm{w})$ \\
\hline \multicolumn{3}{|l|}{ 1:3 GPM:GPS } \\
\hline After freeze-drying & $40.3 \pm 2.2$ & $3.6 \%$ \\
\hline After storage & $36.7 \pm 1.8$ & $4.0 \%$ \\
\hline \multicolumn{3}{|l|}{ 1:1 GPM:GPS } \\
\hline After freeze-drying & $49.3 \pm 1.3$ & $3.1 \%$ \\
\hline After storage & $40.5 \pm 3.9$ & $3.8 \%$ \\
\hline \multicolumn{3}{|l|}{ 2:1 GPM:GPS } \\
\hline After freeze-drying & $51.5 \pm 4.3$ & $2.6 \%$ \\
\hline After storage & $45.1 \pm 2.7$ & $3.2 \%$ \\
\hline \multicolumn{3}{|l|}{ 1:0 GPM:GPS } \\
\hline After freeze-drying & $58.9 \pm 1.9$ & $2.2 \%$ \\
\hline After storage & $48.7 \pm 3.1$ & $2.8 \%$ \\
\hline \multicolumn{3}{|l|}{ Sucrose } \\
\hline After freeze-drying & $63.5 \pm 2.4$ & $1.9 \%$ \\
\hline After storage & $53.7 \pm 2.9$ & $3.0 \%$ \\
\hline
\end{tabular}

496 Isomalt diastereomer mixtures and sucrose are crystalline before lyophilization (Carstensen and 497 Van Scoik 1990; Koskinen, et al. 2016). The crystallinity of the isomalt/sucrose and TRIS mixtures 498 before freeze-drying was confirmed by performing DSC on the mixtures of the different 499 unprocessed isomalt grades and sucrose mixed with TRIS (Table 2). Sucrose and TRIS exhibited 500 only one peak at $135.7^{\circ} \mathrm{C}$ (below the maximum measured temperature of $160^{\circ} \mathrm{C}$ ), which was 501 appointed as melting of TRIS since we measured also pure TRIS, which exhibited a melting peak at $502138.8^{\circ} \mathrm{C}$ (onset $134.4^{\circ} \mathrm{C}$ ). A melting point of $191.5^{\circ} \mathrm{C}$ has previously been measured for D-sucrose, 503 although it also starts to decompose around this temperature (Hurtta, et al. 2004). Out of the four 
different isomalt mixtures, 1:3, 1:1, and 1:0 GPM:GPS showed three endothermic peaks, while 2:1

505 GPM:GPS showed two peaks (Table 2). All four isomalt and TRIS mixtures had a melting peak of 506 TRIS at approximately $135^{\circ} \mathrm{C}$. Previously, for pure isomalt diastereomer mixtures endotherms 507 around $100^{\circ} \mathrm{C}$ were interpreted as dehydration (observed with 1:3, 1:1 and 2:1 GPM:GPS), 508 endotherms at $128^{\circ} \mathrm{C}-135^{\circ} \mathrm{C}$ as dissolution of anhydrous GPM and GPS (observed with 1:1 and 2:1 509 GPM:GPS), an endotherm at $151^{\circ} \mathrm{C}$ as melting of anhydrous GPM and GPS (observed with 1:3 510 GPM:GPS), an endotherm at $112^{\circ} \mathrm{C}$ as melting of GPM dihydrate (observed with 1:0 GPM:GPS), 511 and an endotherm at $127^{\circ} \mathrm{C}$ as dissolution/melting of GPM anhydrate (observed with 1:0 512 GPM:GPS) (Koskinen, et al. 2016). In the present study, the endotherms recorded below $100^{\circ} \mathrm{C}$ for 513 all isomalt and TRIS mixtures are likely due to dehydration based on their shape and temperature 514 range. The other peaks at $129.8^{\circ} \mathrm{C}(1: 3 \mathrm{GPM}: \mathrm{GPS}), 128.2^{\circ} \mathrm{C}(1: 1 \mathrm{GPM}: \mathrm{GPS})$, and at $109.7^{\circ} \mathrm{C}(1: 0$ 515 GPM:GPS) can be due to similar events as observed in the thermograms of their pure diastereomer 516 counterparts listed above (Koskinen, et al. 2016). Having said this, appointing the cause of the 517 endotherms is not completely undisputable, given that the samples are mixtures of two excipients, 518 which can have an interaction.

Table 2. DSC thermal events observed for unprocessed isomalt/sucrose and TRIS mixtures

\begin{tabular}{|c|c|c|c|c|c|c|}
\hline & \multicolumn{2}{|c|}{ Endotherm 1} & \multicolumn{2}{|c|}{ Endotherm 2} & \multicolumn{2}{|c|}{ Endotherm 3} \\
\hline & Onset $\left[{ }^{\circ} \mathrm{C}\right]$ & Peak $\left[{ }^{\circ} \mathrm{C}\right]$ & Onset $\left[{ }^{\circ} \mathrm{C}\right]$ & Peak $\left[{ }^{\circ} \mathrm{C}\right]$ & Onset $\left[{ }^{\circ} \mathrm{C}\right]$ & Peak $\left[{ }^{\circ} \mathrm{C}\right]$ \\
\hline 1:3 GPM:GPS & 69.7 & 90.7 & 121.1 & 129.8 & 133.3 & 135.7 \\
\hline 1:1 GPM:GPS & 70.6 & 87.1 & 118.2 & 128.2 & 133.8 & 135.8 \\
\hline 2:1 GPM:GPS & 83.8 & 96.6 & 133.2 & 135.4 & - & - \\
\hline 1:0 GPM:GPS & 72.3 & 103.8 & 104.7 & 109.7 & 132.9 & 135.5 \\
\hline Sucrose & 133.0 & 135.7 & - & - & - & - \\
\hline
\end{tabular}

522 The different isomalt samples remained physically stable during the storage period, which is likely

523 to be one of the reasons why isomalt mixtures were able to stabilize the protein activity during 524 storage. Also, in previous studies, amorphous isomalt has exhibited high physicochemical stability 
at different humidities and temperatures, which supports its potential as a freeze-drying excipient in

526 protein formulations (Koskinen, et al. 2016; Lipiäinen, et al. 2016).

527 The inferior ability of sucrose to preserve enzymatic activity of LDH during storage may be due to

528 a number of reasons. The alterations in secondary structure of $\mathrm{LDH}$, as revealed by $\mathrm{CD}$, explain

529 partly why sucrose was unsuccessful in preserving LDH activity during storage. The $\mathrm{T}_{\mathrm{g}}$ of sucrose-

530 containing samples decreased from 63.5 to $53.7^{\circ} \mathrm{C}$, which can also reflect decrease in LDH stability,

531 as reduced protein stability may be linked with the decrease of $\mathrm{T}_{\mathrm{g}}$ closer to storage temperature.

532 This is because a lower product $\mathrm{T}_{\mathrm{g}}$ enables greater protein molecular mobility and thus increases

533 protein reactivity (Chang, et al. 2005a; Pikal, et al. 1991). High hydrogen bond formation between

534 freeze-dried amorphous sucrose and LDH has been observed to result in efficient protein

535 stabilization during storage, which deteriorated when the crystalline nature of sucrose increased

536 (Suzuki, et al. 1999). In this current study however, the DSC measurements did not indicate

537 crystallization of sucrose (no crystallization peak was observed), which would have been a clear

538 reason for inefficient stabilization during storage. Since amorphous sucrose is hygroscopic

539 (Carstensen and Van Scoik 1990), the moisture content of the samples was increased during storage

540 and this may also have an inferior effect on the protein stability. Due to an increase in the water

541 content, the viscosity of the amorphous phase of sucrose samples might have been decreased and

542 consequently protein degradation rate could have increased. On the other hand, similar moisture

543 contents have been found to be optimal for protein stability in a sucrose-containing IgG1 antibody

544 formulation (Chang, et al. 2005b), so the effect of moisture uptake is not straightforward. In a

545 previous study, it has been observed that the residual moisture of the protein sample has an effect on

546 the activity of freeze-dried LDH. High residual moisture was associated with high relative activity

547 after freeze-drying, with a residual moisture of $20 \%$ or higher yielded almost $100 \%$ relative activity

548 of lyophilized LDH (Jiang and Nail 1998). In the study however, the protein was freeze-dried in

549 buffer solution without any other excipients. Moisture contents as high as these can cause other 
stability problems in a freeze-dried protein formulation containing stabilizing excipients during

551 storage because in the solid state water can act as a reactant and also dramatically lower the $\mathrm{T}_{\mathrm{g}}$ of 552 the formulation (Chang, et al. 2005b). In this current study, residual water contents of only 1.4$553 \quad 3.6 \%$ were measured after freeze-drying, depending on the sugar excipient included in the 554 formulation. In literature, in a saccharide-containing protein formulation water uptake during 555 storage increased molecular mobility in the glassy matrix but did not clearly increase the aggregation rate of the protein with water content increase (Chang, et al. 2005b). For a lyophilized IgG1 antibody formulation a moisture content of 2-3\%, which falls in the same region as the samples in this current study exhibited after lyophilization, was optimal for protein stability and provided a minimum protein aggregation rate out of the water contents studied (0-5\%) (Chang, et al. 2005b).

\section{CONCLUSIONS}

564 Both sucrose and isomalt were able to stabilize LDH during freeze-drying to some extent as evidenced by the lower relative enzymatic activity in samples containing no sugar excipients. Sucrose performed clearly better than isomalt as a cryo- and lyostabilizing excipient preserving

567 LDH activity almost fully after freeze-drying. However, during storage the samples stabilized with 568 sucrose lost over half of their initial activity, whereas isomalt protected LDH better from the 569 storage-induced destabilizing effects. The low protein activity level after storage suggests that 570 sucrose was not able to stabilize LDH efficiently in the presence of moisture. During storage, the 571 significance of stabilizing sugar excipients was emphasized as LDH samples without sugars lost 572 their activity almost completely, with only a quarter of the pre-storage LDH activity remaining after 573 the storage period. Even though isomalt was not the most optimal stabilizing excipient for the 
studied protein during lyophilization, it showed some protein-stabilizing effects, especially during

575 the storage stability studies. In future studies, the aggregation tendency of lyophilized LDH

576 stabilized with isomalt should be investigated to assess whether aggregation takes place and does it

577 affect LDH stability. In order to assess the potential of isomalt as a novel cryo- and lyoprotecting

578 excipient in freeze-dried protein formulations, more freeze-drying studies should be carried out with

579 different proteins and in combinations with other excipients. Before isomalt could be used as an

580 excipient in freeze-dried formulations intended for parenteral use, also its intravenous toxicity must 581 be studied.

\section{ACKNOWLEDGEMENTS}

The authors wish to acknowledge Beneo-Palatinit $\mathrm{GmbH}$ for kindly donating the isomalt grades used in the study. Dr. Luis Bimbo from the Strathclyde Institute of Pharmacy and Biomedical Sciences, University of Strathclyde, is acknowledged for his assistance with carrying out the CD spectroscopy measurements. We acknowledge Dr. Petteri Heljo from the Formulation Research DSC measurements. 
This work was supported by the Finnish Pharmaceutical Society.

\section{REFERENCES}

Al-Hussein, A., Gieseler, H., 2012. The Effect of Mannitol Crystallization in Mannitol-Sucrose systems on LDH Stability during Freeze-Drying. J. Pharm. Sci., 101, 2534-2544. doi: https://doi.org/10.1002/jps.23173.

Allison, S.D., Chang, B., Randolph, T.W., Carpenter, J.F., 1999. Hydrogen Bonding between Sugar and Protein Is Responsible for Inhibition of Dehydration-Induced Protein Unfolding. Arch. Biochem. Biophys., 365, 289-298. doi: http://dx.doi.org/10.1006/abbi.1999.1175.

Anchordoquy, T.J., Carpenter, J.F., 1996. Polymers protect lactate dehydrogenase during freezedrying by inhibiting dissociation in the frozen state. Arch. Biochem. Biophys., 332, 231-238. doi: http://dx.doi.org/10.1006/abbi.1996.0337.

Anchordoquy, T.J., Izutsu, K., Randolph, T.W., Carpenter, J.F., 2001. Maintenance of Quaternary Structure in the Frozen State Stabilizes Lactate Dehydrogenase during Freeze-Drying. Arch. Biochem. Biophys., 390, 35-41. doi: http://dx.doi.org/10.1006/abbi.2001.2351.

British Pharmacopoeia Commission, 2015. British Pharmacopoeia 2015, TSO, London, UK.

Cammenga, H.K., Zielasko, B., 1996. Thermal behaviour of isomalt. Thermochim. Acta, 271, 149153. doi: http://dx.doi.org/10.1016/0040-6031(95)02560-X.

Carstensen, J.T., Van Scoik, K., 1990. Amorphous-to-Crystalline Transformation of Sucrose. Pharm. Res., 7, 1278-1281. doi: http://dx.doi.org/10.1023/A:1015942022789.

Chang, L.(., Shepherd, D., Sun, J., Ouellette, D., Grant, K.L., Tang, X.(., Pikal, M.J., 2005a. Mechanism of protein stabilization by sugars during freeze-drying and storage: Native structure preservation, specific interaction, and/or immobilization in a glassy matrix? J. Pharm. Sci., 94, 1427-1444. doi: http://dx.doi.org/10.1002/jps.20364.

Chang, L.(., Shepherd, D., Sun, J., Tang, X.(., Pikal, M.J., 2005b. Effect of sorbitol and residual moisture on the stability of lyophilized antibodies: Implications for the mechanism of protein stabilization in the solid state. J. Pharm. Sci., 94, 1445-1455. doi: http://dx.doi.org/10.1002/jps.20363.

Chang, L., Pikal, M.J., 2009. Mechanisms of protein stabilization in the solid state. J. Pharm. Sci., 98, 2886-2908. doi: http://dx.doi.org/10.1002/jps.21825.

Chatterjee, K., Shalaev, E.Y., Suryanarayanan, R., 2005. Partially crystalline systems in lyophilization: II. Withstanding collapse at high primary drying temperatures and impact on protein activity recovery. J. Pharm. Sci., 94, 809-820. doi: http://dx.doi.org/10.1002/jps.20304. 
Cochran, T., Nail, S.L., 2009. Ice nucleation temperature influences recovery of activity of a model protein after freeze drying. J. Pharm. Sci., 98, 3495-3498. doi: http://dx.doi.org/10.1002/jps.21815.

631 Costantino, H.R., Carrasquillo, K.G., Cordero, R.A., Mumenthaler, M., Hsu, C.C., Griebenow, K., 632 1998. Effect of excipients on the stability and structure of lyophilized recombinant human growth 633 hormone. J. Pharm. Sci., 87, 1412-1420. doi: http://dx.doi.org/10.1021/js980069t.

634 Cromwell, M.E.M., Hilario, E., Jacobson, F., 2006. Protein aggregation and bioprocessing. AAPS 635 J., 8, E572-E579. doi: http://dx.doi.org/10.1208/aapsj080366.

European Pharmacopoeia Online 9th Edition 2017 (9.2). http://online6.edqm.eu/ep902/ (accessed 01.07.2017).

EvaluatePharma, 2015. World Preview 2015, Outlook to 2020, eighth ed.

http://info.evaluategroup.com/rs/607-YGS-364/images/wp15.pdf (accessed 02.05.2017).

640 Fonte, P., Soares, S., Sousa, F., Costa, A., Seabra, V., Reis, S., Sarmento, B., 2014. Stability Study

Hagen, S., Hofrichter, J., Eaton, W., 1995. Protein reaction kinetics in a room-temperature glass.

Jaenicke, R., 1990. Protein Structure and Function at Low Temperatures. Phil. Trans. R. Soc. Lond. B, 326, 535-553. doi: http://dx.doi.org/10.1098/rstb.1990.0030.

Jiang, S., Nail, S.L., 1998. Effect of process conditions on recovery of protein activity after freezing and freeze-drying. Eur. J. Pharm. Biopharm., 45, 249-257. doi: http://dx.doi.org/10.1016/S09396411(98)00007-1. 389, 107-113. doi: http://dx.doi.org/10.1016/j.ijpharm.2010.01.027.

Kawai, K., Suzuki, T., 2007. Stabilizing Effect of Four Types of Disaccharide on the Enzymatic 
Kouassi, G.K., Anantheswaran, R.C., Knabel, S.J., Floros, J.D., 2007. Effect of High-Pressure Processing on Activity and Structure of Alkaline Phosphatase and Lactate Dehydrogenase in Buffer and Milk. J. Agric. Food Chem., 55, 9520-9529. doi: http://dx.doi.org/10.1021/jf071518q.

668

669

Leblanc, Y., Bihoreau, N., Jube, M., Andre, M.-., Tellier, Z., Chevreux, G., 2016. Glycation of polyclonal IgGs: Effect of sugar excipients during stability studies. Eur. J. Pharm. Biopharm., 102, 185-190. doi: https://doi.org/10.1016/j.ejpb.2016.03.016.

Lipiäinen, T., Peltoniemi, M., Räikkönen, H., Juppo, A., 2016. Spray-dried amorphous isomalt and melibiose, two potential protein-stabilizing excipients. Int. J. Pharm., 510, 311-322. doi: http://dx.doi.org/10.1016/j.ijpharm.2016.06.038.

Luthra, S., Obert, J., Kalonia, D.S., Pikal, M.J., 2007. Investigation of drying stresses on proteins during lyophilization: Differentiation between primary and secondary-drying stresses on lactate dehydrogenase using a humidity controlled mini freeze-dryer. J. Pharm. Sci., 96, 61-70. doi: http://dx.doi.org/10.1002/jps.20758.

Mensink, M.A., Frijlink, H.W., van der Voort Maarschalk, K., Hinrichs, W.L.J., 2017. How sugars protect proteins in the solid state and during drying (review): Mechanisms of stabilization in relation to stress conditions. Eur. J. Pharm. Biopharm., 114, 288-295. doi: https://doi.org/10.1016/j.ejpb.2017.01.024.

Mi, Y., Wood, G., 2004. The Application and Mechanisms of Polyethylene Glycol 8000 on Stabilizing Lactate Dehydrogenase during Lyophilization. PDA J. Pharm. Sci. Tech., 58, 192-202.

Mi, Y., Wood, G., Thoma, L., Rashed, S., 2002. Effects of Polyethylene Glycol Molecular Weight and Concentration on Lactate Dehydrogenase Activity in Solution and After Freeze-thawing. PDA J. Pharm. Sci. Tech., 56, 115-123.

Musch, V.K., Siebert, G., Schiweck, H., Steinle, G., 1973. Physiological-nutritional studies on the utilization of isomaltitol in rats. Z. Ernährungswiss. Suppl., 3-16.

Ndindayino, F., Henrist, D., Kiekens, F., Van den Mooter, G., Vervaet, C., Remon, J.P., 2002. Direct compression properties of melt-extruded isomalt. Int. J. Pharm., 235, 149-157. doi: http://dx.doi.org/10.1016/S0378-5173(01)00993-0.

Ohtake, S., Kita, Y., Arakawa, T., 2011. Interactions of formulation excipients with proteins in solution and in the dried state. Adv. Drug Deliv. Rev., 63, 1053-1073. doi: http://doi.org/10.1016/j.addr.2011.06.011.

Pikal, M.J., Dellerman, K.M., Roy, M.L., Riggin, R.M., 1991. The Effects of Formulation Variables on the Stability of Freeze-Dried Human Growth Hormone. Pharm. Res., 8, 427-436. doi: http://dx.doi.org/10.1023/A:1015834724528.

Sáska, Z., Dredán, J., Balogh, E., Luhn, O., Shafir, G., Antal, I., 2010. Effect of isomalt as novel binding agent on compressibility of poorly compactable paracetamol evaluated by factorial design. Powder Technol., 201, 123-129. doi: http://dx.doi.org/10.1016/j.powtec.2010.03.009. 
Schersch, K., Betz, O., Garidel, P., Muehlau, S., Bassarab, S., Winter, G., 2010. Systematic investigation of the effect of lyophilizate collapse on pharmaceutically relevant proteins I: Stability after freeze-drying. J. Pharm. Sci., 99, 2256-2278. doi: https://doi.org/10.1002/jps.22000.

704

705

706

707

708

709

710

711

712

713

714

715

716

717

718

719

720

721

722

723

724

725

726

727

728

729

730

731

732

733

734

735

736

737

Schersch, K., Betz, O., Garidel, P., Muehlau, S., Bassarab, S., Winter, G., 2012. Systematic Investigation of the Effect of Lyophilizate Collapse on Pharmaceutically Relevant Proteins, Part 2: Stability During Storage at Elevated Temperatures. J. Pharm. Sci., 101, 2288-2306. doi: https://doi.org/10.1002/jps.23121.

Schersch, K., Betz, O., Garidel, P., Muehlau, S., Bassarab, S., Winter, G., 2013. Systematic investigation of the effect of lyophilizate collapse on pharmaceutically relevant proteins III: Collapse during storage at elevated temperatures. Eur. J. Pharm. Biopharm., 85, 240-252. doi: https://doi.org/10.1016/j.ejpb.2013.05.009.

Schwegman, J.J., Hardwick, L.M., Akers, M.J., 2005. Practical Formulation and Process Development of Freeze-Dried Products. Pharm. Dev. Technol., 10, 151-173. doi: http://dx.doi.org/10.1081/PDT-56308.

Sentko A., Willibald-Ettle I., 2012. Isomalt, in: O'Donnell K., Kearsley M.W. (Eds.), Sweeteners and Sugar Alternatives in Food Technology, second ed. Wiley-Blackwell, Chichester. pp. 243-274.

Singh, S.K., Kolhe, P., Mehta, A.P., Chico, S.C., Lary, A.L., Huang, M., 2011. Frozen State Storage Instability of a Monoclonal Antibody: Aggregation as a Consequence of Trehalose Crystallization and Protein Unfolding. Pharm. Res., 28, 873-885. doi: http://dx.doi.org/10.1007/s11095-010-0343-z.

Smits-Van Prooije, A.E., De Groot, A.P., Dreef-Van Der Meulen, H.C., Sinkeldam, E.J., 1990. Chronic toxicity and carcinogenicity study of isomalt in rats and mice. Food Chem. Toxicol., 28, 243-251. doi: http://dx.doi.org/10.1016/0278-6915(90)90036-M.

Sundaramurthi, P., Suryanarayanan, R., 2010. Trehalose Crystallization During Freeze-Drying: Implications On Lyoprotection. J. Phys. Chem. Lett., 1, 510-514. doi: http://dx.doi.org/10.1021/jz900338m.

Suzuki, T., Imamura, K., Fujimoto, H., Okazaki, M., 1999. Role of Sucrose-LDH Hydrogen Bond for Thermal Stablizing Effect of Sucrose on Freeze-dried LDH. Drying Technol, 17, 1429-1439. doi: http://dx.doi.org/10.1080/07373939908917625.

Thiebaud, D., Jacot, E., Schmitz, H., Spengler, M., Felber, J.P., 1984. Comparative study of isomalt of sucrose by means of continuous indirect calorimetry. Metabolism, 808-813. doi: http://dx.doi.org/10.1016/0026-0495(84)90106-9.

Timasheff, S.N., 1998. Control of Protein Stability and Reactions by Weakly Interacting Cosolvents: The Simplicity of the Complicated. Adv. Protein Chem., 51, 355-432. doi: http://dx.doi.org/10.1016/S0065-3233(08)60656-7.

United States Pharmacopeial Convention, 2014. United States Pharmacopeia and National Formulary (USP 38-NF 33), United States Pharmacopeial; Slp edition (May 2015), Rockville, MD. 
738 Urbani, R., Sussich, F., Prejac, S., Cesàro, A., 1997. Enthalpy relaxation and glass transition 739 behaviour of sucrose by static and dynamic DSC. Thermochim. Acta, 304-305, 359-367. doi: $740 \quad$ http://dx.doi.org/10.1016/S0040-6031(97)00094-4.

741 Waalkens-Berendsen, D.H., Koëter, H.B.W.M., Sinkeldam, E.J., 1990a. Multigeneration 742 reproduction study of isomalt in rats. Food Chem. Toxicol., 28, 11-19. doi:

743 http://dx.doi.org/10.1016/0278-6915(90)90130-F.

744 Waalkens-Berendsen, D.H., Koëter, H.B.W.M., van Marwijk, M.W., $1990 \mathrm{~b}$.

745 Embryotoxicity/teratogenicity of isomalt in rats and rabbits. Food Chem. Toxicol., 28, 1-9. doi: 746 http://dx.doi.org/10.1016/0278-6915(90)90129-B.

747 Wang, W., Singh, S., Zeng, D.L., King, K., Nema, S., 2007. Antibody structure, instability, and 748 formulation. J. Pharm. Sci., 96, 1-26. doi: http://dx.doi.org/10.1002/jps.20727.

749 World Health Organization, 1987. Isomalt in: Toxicological evaluation of certain food additives and 750 contaminants. (WHO Food Additives Series No. 20).

751 http://www.inchem.org/documents/jecfa/jecmono/v20je14.htm (accessed 15.03.2017). 